\title{
Seasonal effects on seminal and endocrine traits in the captive snow leopard (Panthera uncia)
}

\author{
L. A. Johnston ${ }^{1}$, D. L. Armstrong ${ }^{1}$ and J. L. Brown ${ }^{2,3}$ \\ ${ }^{1}$ Omaha's Henry Doorly Zoo, 3701 South 10th St, Omaha, NE 68107, USA; ${ }^{2}$ National Zoological Park, \\ Smithsonian Institution, Washington, DC 20008, USA; and ${ }^{3}$ Conservation and Research Center,
}

1500 Remount Road, Front Royal, VA 22630, USA

\begin{abstract}
The annual reproductive cycle of the male snow leopard (Panthera uncia) was characterized by evaluating seminal and endocrine traits monthly. Testicular volume was greatest $(P<0.05)$ during the winter months when the quality of ejaculate was optimal. Ejaculate volume, total sperm concentration $\mathrm{ml}^{-1}$, motile sperm concentration per ejaculate, sperm morphology and sperm motility index were lowest during the summer and autumn months compared with the winter and spring. Peripheral LH, FSH and testosterone concentrations were also lowest during the summer months, increasing during the autumn just before the increase in semen quality, and were maximal during the winter months. There was a direct relationship $(P<0.01)$ between: $(1)$ testosterone and testicular volume, total sperm concentration $\mathrm{ml}^{-1}$, motile sperm concentration per ejaculate and ejaculate volume, and (2) $\mathrm{LH}$ and testicular volume and motile sperm concentration per ejaculate. In summary, although spermatozoa were recovered throughout the year, optimal gamete quality was observed during the winter and spring. Although previous studies in felids have demonstrated seasonal effects on either seminal or endocrine traits, this is the first study to demonstrate a distinct effect of season on both pituitary and testicular function.
\end{abstract}

\section{Introduction}

The Felidae represents a unique taxon comprising 37 species, many of which have adapted to a wide array of environmental conditions in the wild. The snow leopard (Panthera uncia) inhabits alpine and subalpine areas of central Asia at $5000 \mathrm{~m}$, descending only in the winter to about $1500 \mathrm{~m}$ (Jackson, 1991). The species has an enormous range across 12 international boundaries, from the Hindu Kush mountains of Afghanistan to the Himalayan mountains of Nepal and Bhutan. Owing to the isolated and rugged terrain in which it is found, the snow leopard is one of the least-studied large cat species. The snow leopard is considered a highly endangered species, and numbers in the wild have been greatly reduced as a result of: (1) eradication of its prey base; (2) poaching for the fur trade; (3) human encroachment on habitat; and (4) human persecution. Because of the discontinuity of its mountainous habitat, snow leopards do not occupy a continuous range, but rather exist in many subpopulations. Although the prey base of the snow leopard has been increasing in some regions of its range (Smirnov et al., 1990), it is not known whether these subpopulations are viable, or whether sufficient exchange of genetic material can occur between subpopulations without positive human intervention.

Reproductive success is the key to species survival. However, it is well known that when the effective population size is

Revised manuscript received 26 April 1994 reduced, genetic diversity is depleted and a cascade of events takes place that causes an immediate loss of fitness and a long-term loss of evolutionary potential and flexibility (Gilpin and Soule, 1986). There are over 200 snow leopards in captivity worldwide, and managed captive breeding programmes have been established in North America and Europe (Blomqvist, 1990). Recently, captive propagation has become an integral component of snow leopard conservation through genetically managed captive breeding programmes using assisted reproductive technology such as artificial insemination and in vitro fertilization (Ballou, 1992; Wildt, 1992). However, to make efficient use of assisted reproductive strategies in the management of this species, it is essential that we first understand basic reproductive characteristics including seasonal influences on snow leopard reproductive capacity. The objectives of this study were ( 1 ) to examine the annual testicular cycle of the male snow leopard, including seminal and endogenous hormonal characteristics, and (2) to analyse parturition records to determine any potential seasonal effect on the oestrous cycle of the female.

\section{Materials and Methods}

\section{Animals}

Three adult male snow leopards of prime breeding age $(7,9$ and 11 years) were maintained at the Henry Doorly Zoo, 
Omaha, NE (latitude $41^{\circ}$, longitude $96^{\circ}$ ). All males are proven breeders and have sired offspring as recently as 1991. Except during the breeding season, males were housed individually in indoor-outdoor enclosures and exposed to the natural photoperiod throughout the year. A commercial, nondomestic carnivore diet (I \& M Industries, Lincoln, NE) was provided 6 days a week.

\section{Electroejaculation, collection of blood samples and semen evaluation}

One day each month ( $n=12$ evaluations per male), males were anaesthetized ( $14.2 \mathrm{mg}$ ketamine $\mathrm{kg}^{-1}$ and $0.5 \mathrm{mg}$ xylazine $\mathrm{kg}^{-1}$ ) by blow darting, and semen was collected using a standardized electroejaculation technique (Wildt et al., 1983). Briefly, a rectal probe (diameter, $2.5 \mathrm{~cm}$; length, $26 \mathrm{~cm}$ ) and electrostimulator (AC, $60 \mathrm{~Hz}$ current; P-T Electronics, Boring, OR) were used to deliver a regimented electroejaculation sequence consisting of a total of 80 stimuli given in three series (I, II, III). The length and width of each testis was measured and the values were converted to testicular volume (V) using the formula for a prolate sphere $\left(V=\frac{4}{3} \pi a b^{2}\right.$, where $a=\frac{1}{2}$ length and $b=\frac{1}{2}$ width; Howard et al., 1986). The volumes for the right and left testes were combined to obtain the total testicular volume per male.

Blood samples $(5-10 \mathrm{ml})$ were collected by saphenous venepuncture immediately before the onset of electroejaculation, immediately after each series of electroejaculations and $15 \mathrm{~min}$ after electroejaculation. Samples were centrifuged at $20^{\circ} \mathrm{C}$ (1200 g, $\left.20 \mathrm{~min}\right) 1 \mathrm{~h}$ after collection, and the recovered sera stored at $-20^{\circ} \mathrm{C}$ until hormone analysis by radioimmunoassay.

Semen from each series of ejaculations was immediately evaluated for percentage sperm motility and progressive status (at a magnification of $\times 200$ ); the speed of forward progression was based on a scale of 0 (no movement) to 5 (rapid forward movement) (Wildt et al., 1983). The spermatozoa were then pooled and evaluated for total ejaculate volume, percentage motility and progressive status. Semen was then diluted to $0.5 \times 10^{6}$ motile spermatozoa $\mathrm{ml}^{-1}$ in Sperm Washing Medium (SWM; Irvine Scientific, Irvine, $\mathrm{CA}$ ), maintained at $37^{\circ} \mathrm{C}$ and evaluated every $2 \mathrm{~h}$ for a total of $6 \mathrm{~h}$ for motility and progressive status. For each ejaculate, a sperm motility index (SMI) was calculated to provide an overall evaluation of sperm motility characteristics $(\mathrm{SMI}=[$ sperm \% motility $+($ forward progressive motility $\times 20)] / 2$ ) (Howard et al., 1990). An undiluted aliquot of $10 \mu \mathrm{l}$ of semen was used to determine the sperm concentration in a haemocytometer (Wildt et al., 1983). Sperm morphology evaluations were performed by fixing a $25 \mu \mathrm{l}$ aliquot in $100 \mu \mathrm{l}$ of $1 \%$ glutaraldehyde and examining 150-200 individual sperm cells using phase contrast microscopy ( $\times 1000)$ (Wildt et al., 1983). Spermatozoa were classified as normal or having one of the following abnormalities: macrocephalic; microcephalic; bicephalic; malformed head shape; malformed acrosome; mitochondrial sheath aplasia (including segmental or complete aplasia of the mitochondrial sheath); tightly coiled flagellum; biflagellate; bent flagellum; bent neck; bent midpiece with or without cytoplasmic droplet; and a proximal or distal cytoplasmic droplet.

\section{Radioimmunoassays}

LH. Serum LH was measured using a heterologous doubleantibody radioimmunoassay described by Brown et al. (1991a). The assay used a rabbit anti-bovine first antibody (PKC-242; J. L. Brown, Uniformed Services University, Bethesda, MD), an ovine LH label (LER-1374-A; L. E. Riechert, Jr, Albany Medical School, Albany, NY), an ovine LH standard (NIH-LH-SI8; NIDDK, National Hormone and Pituitary Program, Rockville, $\mathrm{MD)}$ and a sheep anti-rabbit $\gamma$-globulin second antibody in a phosphate-based buffer system $\left(0.01 \mathrm{~mol}\right.$ phosphate $1^{-1}$, $0.14 \mathrm{~mol} \mathrm{NaCl}^{-1}, 0.002 \mathrm{~mol} \mathrm{EDTA}^{-1}, 0.5 \% \mathrm{BSA}, \mathrm{pH} 7.4$ ). The assay was modified to accommodate a smaller incubation volume $(300 \mu \mathrm{l}$ compared with $1000 \mu \mathrm{l})$ and a shorter incubation time ( 3 days compared with 7 days).

Briefly, serum or standard $(100 \mu \mathrm{l})$ and first antibody $(100 \mu \mathrm{l}$; 1:200 000 final dilution) were added on day $\mathrm{I}$ and incubated for $24 \mathrm{~h}$ at room temperature. On day $2,{ }^{125}$ I-labelled LH (100 $\mu \mathrm{l}$, approximately 20000 c.p.m.) was added and incubated for an additional $24 \mathrm{~h}$ at room temperature. Separation of free from antibody-bound hormone was achieved on day 3 after incubation for $1 \mathrm{~h}$ with $1 \mathrm{ml}$ buffer containing second antibody (1:1000 final dilution) and $5 \%$ polyethylene glycol $(8000 \mathrm{kDa}$, Sigma Chemical Co., St Louis, MO) and centrifugation at $3000 \mathrm{~g}$ for $30 \mathrm{~min}$ at $4^{\circ} \mathrm{C}$. The $\mathrm{LH}$ antiserum bound $25 \%$ of the ${ }^{125} \mathrm{I}$-labelled $\mathrm{LH}$. The standard curve ranged from 0.016 to $4.0 \mathrm{ng}$ per tube with an $\mathrm{ED}_{50}$ value of $0.21 \mathrm{ng}$ per tube. Assay sensitivity (determined as $90 \%$ of maximum binding) was $0.02 \mathrm{ng}$ per tube $\left(0.2 \mathrm{ng} \mathrm{ml}^{-1}\right)$. The assay was validated for the snow leopard by demonstrating parallelism between dilutions of serum and the LH standard curve. Addition of $0.063,0.125$, $0.25,0.5,1$ and $2 \mathrm{ng}$ ovine $\mathrm{LH}$ to snow leopard serum resulted in a recovery of $101 \%$ after subtraction of endogenous hormone $(y=0.98 x+0.01 ; r=0.99)$. All samples were analysed in a single assay with a $5.6 \%$ intra-assay coefficient of variation.

\section{FSH. Serum FSH was measured using a radioimmunoassay} (Brown et al., 1987) previously validated for felid serum (Brown et al., 1988, 1991b). The assay used a rabbit anti-ovine FSH first antibody (JAD 178; J. A. Dias, Wadsworth Institute, Albany, NY), an ovine FSH label (LER-1976-A2; L. E. Reichert, Jr), an ovine FSH standard (NIH-FSH-S8; NIDDK, National Hormone and Pituitary Program) and a sheep anti-rabbit $\gamma$-globulin second antibody. The assay was modified as described above for the LH assay. The FSH antiserum bound $30 \%$ of the ${ }^{125} \mathrm{I}$-labelled FSH, and the standard curve ranged from 0.098 to $25.0 \mathrm{ng}$ per tube, with an $\mathrm{ED}_{50}$ value of $3.85 \mathrm{ng}$ per tube. Assay sensitivity was $0.25 \mathrm{ng}$ per tube $\left(2.5 \mathrm{ng} \mathrm{ml}^{-1}\right)$. The assay was validated for the snow leopard by demonstrating parallelism between dilutions of serum and the FSH standard curve. Addition of $0.39,0.78,1.56,3.13,6.25$ and $12.5 \mathrm{ng}$ ovine FSH to snow leopard serum resulted in a net recovery of $98 \%(y=1.02 x-0.05 ; r=0.99)$. All samples were analysed in a single assay with a $6.1 \%$ intra-assay coefficient of variation.

Testosterone. Serum testosterone was measured using a double-antibody ${ }^{125}$ I radioimmunoassay kit (ICN Biomedicals, Inc., Costa Mesa, CA). The assay was validated by demonstrating parallelism between dilutions of unextracted snow leopard serum and the testosterone standard curve. Addition of 0.05 , 
$0.125,0.25,0.5,1.25$ and $2.5 \mathrm{ng}$ testosterone to snow leopard serum resulted in a net recovery of $103 \%(y=1.03 x+0.08$; $r=0.99$ ). The assay sensitivity was $0.05 \mathrm{ng} \mathrm{ml}^{-1}$. All samples were analysed in a single assay with a $5.4 \%$ intra-assay coefficient of variation.

Demography Survey data on captive snow leopard females were taken from the International Snow Leopard Studbook (Blomqvist, 1990). Information on the proportion of parturitions for each month of the year was analysed to determine the effect of season on female reproductive patterns.

Statistical analysis The year was divided into four seasons: winter (Dec-Feb), spring (Mar-May), summer (Jun-Aug) and autumn (Sep-Nov). For each animal, mean ( \pm SEM) values were calculated for seminal and hormonal characteristics $(n=5$ observations per male per evaluation) obtained after each ejaculation procedure; the data were then averaged across that season. All data were analysed using a general linear models program (sOLO, BMDP Statistical Software, Inc., Los Angeles, CA). When a significant $F$ value was calculated $(P<0.05)$, differences among means were determined by a least significant difference multiple-comparison procedure. Correlation coefficients were calculated for relationships between the mean values of various hormone concentrations and ejaculate traits.

\section{Results}

\section{Female seasonality}

Evaluation of 469 snow leopard parturitions within the northern hemisphere demonstrated that births occurred in 7 months of the year, with the greatest number occurring in May $(50.3 \%$; 236 of 469 ) (Fig. 1). Oestrus was observed from January to April, and the duration of gestation was 91-127 days. At the Omaha Zoo, parturitions $(n=7)$ have occurred from March to early August.

\section{Seminal and testis traits}

On the basis of a total of 36 collections, the average ejaculate volume was $1.54 \pm 0.1 \mathrm{ml}$ (range, $0.25-3.2 \mathrm{ml}$ ) containing $29.2 \pm 5.7 \times 10^{6}$ motile spermatozoa $\mathrm{ml}^{-1}$ (range, $1.0-126.2 \times 10^{6}$ ) with an average SMI of $76.5 \pm 2.4$ (range, 43.8-91.3). The mean percentage of morphologically normal spermatozoa was $35.0 \pm 2.1$ (range, $13.0-55.8 \%$ ). Within each season, there were no individual differences $(P>0.05)$ in testicular volume, total sperm concentration $\mathrm{ml}^{-1}$, motile sperm concentration per ejaculate, sperm morphology or SMI.

The testicular volume during the winter $\left(11.4 \pm 1.1 \mathrm{~cm}^{3}\right)$ was greater $(P<0.05)$ than during the spring $\left(9.5 \pm 0.5 \mathrm{~cm}^{3}\right)$, summer $\left(8.9 \pm 0.5 \mathrm{~cm}^{3}\right)$ and autumn $\left(8.8 \pm 0.6 \mathrm{~cm}^{3}\right)$ (Fig. 2a). Values during the spring, summer and autumn were similar $(P>0.05)$.

During the winter, spring and summer, male 2 consistently produced a greater $(P<0.05)$ ejaculate volume than did males 1 and 3 (Fig. 2b). Analysis of the overall ejaculate volume revealed seasonal differences $(P<0.05)$; higher volumes were produced in the spring $(2.00 \pm 0.2 \mathrm{ml})$ compared with during

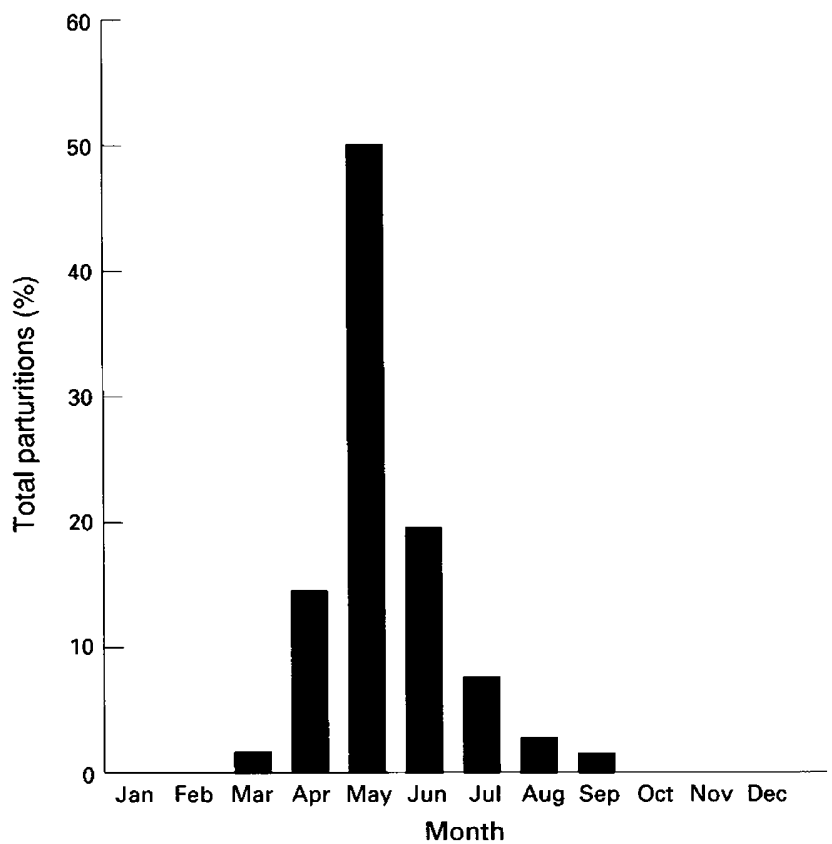

Fig. 1. Percentage of captive snow leopard births per month over the past 15 years.

the summer and autumn $(1.30 \pm 0.1 \mathrm{ml}, 1.30 \pm 0.1 \mathrm{ml}$, respectively). Ejaculate volumes during the winter $(1.79 \pm 0.5 \mathrm{ml})$ were intermediate and not different $(P>0.05)$ from the other three seasons.

The total sperm concentration $\mathrm{ml}^{-1}$ of ejaculate during the winter $\left(36.3 \pm 7.7 \times 10^{6}\right)$ and spring $\left(38.7 \pm 5.3 \times 10^{6}\right)$ was similar $(P>0.05)$ and greater $(P<0.05)$ than during the summer $\left(14.2 \pm 3.1 \times 10^{6}\right)$ and autumn $\left(6.9 \pm 1.3 \times 10^{6}\right)$ (Fig. 2c).

The motile sperm concentration per ejaculate during the winter $\left(65.5 \pm 10.9 \times 10^{6}\right)$ and spring $\left(54.0 \pm 0.9 \times 10^{6}\right)$ was similar $(P>0.05)$, and greater $(P<0.05)$ than during the sum$\operatorname{mer}\left(8.0 \pm 1.3 \times 10^{6}\right)$ and autumn $\left(6.3 \pm 1.1 \times 10^{6}\right)($ Fig. $2 \mathrm{~d})$.

The overall SMI was higher $(P<0.05)$ during the spring $(86.9 \pm 1.1)$ than during the summer and autumn $(69.2 \pm 0.3$ and $72.2 \pm 0.2$, respectively), but was similar $(P>0.05)$ to that observed in the winter $(77.5 \pm 5.5)$ (Fig. 2e). When the SMI was measured $6 \mathrm{~h}$ after collection of the electroejaculate, no differences $(P>0.05)$ were observed among males or seasons (range, 0-57.5; mean, $13.3 \pm 3.2$ ).

Overall, the proportion of structurally normal spermatozoa per ejaculate was similar $(P>0.05)$ during the winter and spring, but was greater $(P<0.05)$ than that during the summer (Table 1$)$. Values in the autumn were lower $(P<0.05)$ than in the winter and were similar $(P>0.05)$ to values obtained during the spring and summer. Across all seasons, the most prevalent abnormalities in spermatozoa were malformed acrosomes, malformed head shapes, a coiled flagellum, a bent midpiece with or without a cytoplasmic droplet, and cytoplas mic droplets (Fig. 3). During the summer and autumn, there was a twofold increase $(P>0.05)$ in the incidence of microcephalic forms, a threefold increase $(P<0.05)$ in mitochondrial sheath abnormalities (segmental or complete aplasia) and a 1.5 -fold increase $(P>0.05)$ in bent midpieces. 

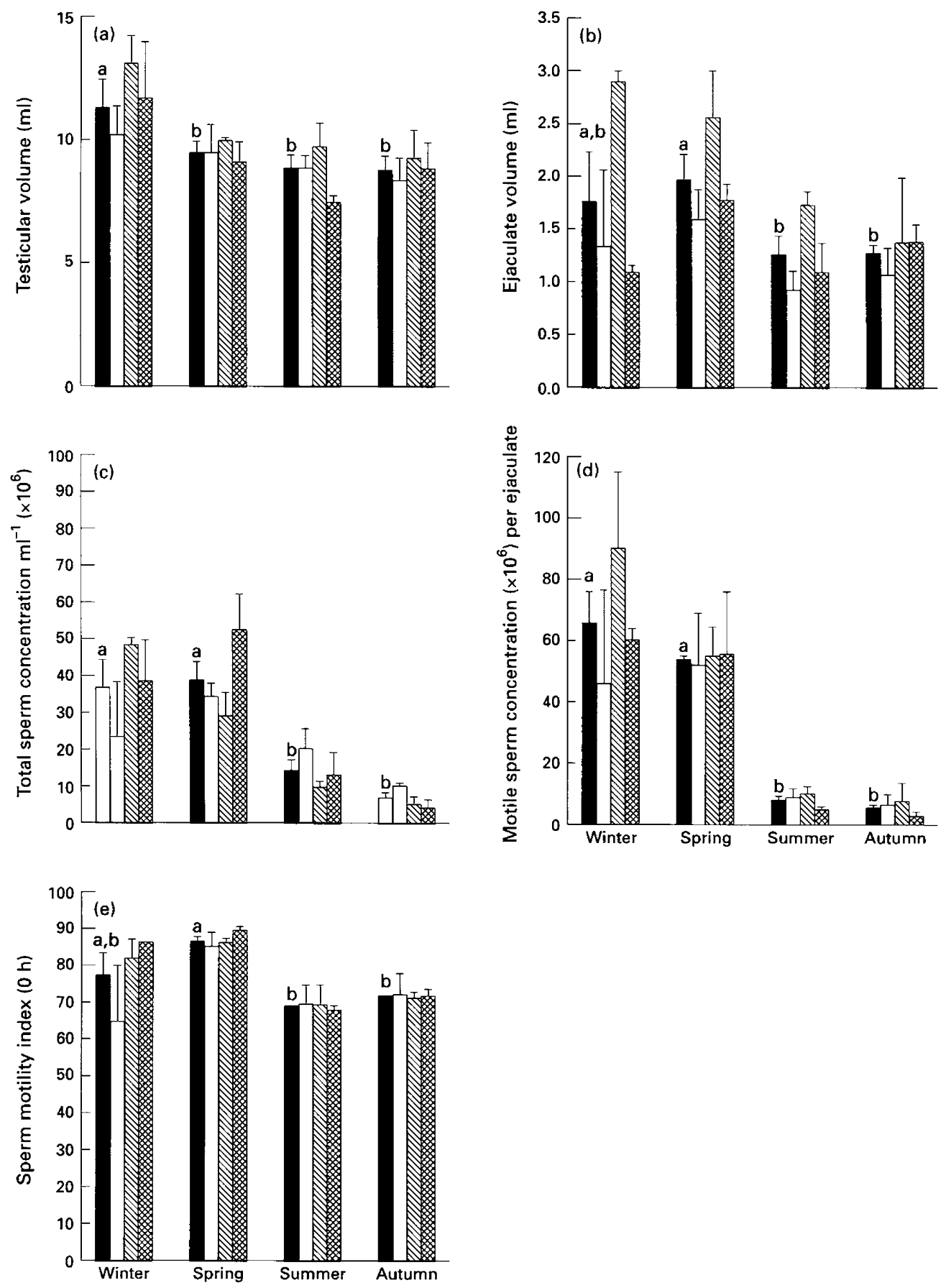

Fig. 2. Mean ( \pm SEM) values for ejaculate characteristics of snow leopards on the basis of season: (a) testicular volume; (b) ejaculate volume; (c) total sperm concentration $\mathrm{ml}^{-1}$; (d) motile sperm concentration per ejaculate; and (e) sperm motility index. The columns represent values combined from all individuals ( $\boldsymbol{\square}$ ), and individual animals: $(\square)$, male 1 ; $(\mathbb{Q})$, male 2 ; $($, male 3. Bars with different superscripts are significantly different between seasons $(P<0.05)$.

\section{Circulating LH, FSH and testosterone concentrations}

There were no individual differences $(P>0.05)$ in the mean serum LH, FSH or testosterone concentrations within season or among the samples collected before, during and after electroejaculation. Seasonal changes in serum hormone concentrations for all animals combined and for individual males are shown (Fig. 4).

Mean LH concentrations were greatest $(P<0.05)$ in the winter $\left(0.78 \pm 0.08 \mathrm{ng} \mathrm{ml}^{-1}\right)$, lowest $(P<0.05)$ in the summer $\left(0.29 \pm 0.01 \mathrm{ng} \mathrm{ml}^{-1}\right)$ and intermediate in the spring $\left(0.38 \pm 0.02 \mathrm{ng} \mathrm{ml}^{-1}\right)$ and autumn $\left(0.46 \pm 0.09 \mathrm{ng} \mathrm{ml}^{-1}\right)$ 
Table 1. Structural morphology of snow leopard spermatozoa

\begin{tabular}{|c|c|c|c|c|}
\hline Description & Winter (Dec-Feb) & Spring (Mar-May) & Summer (Jun-Aug) & Autumn (Sep-Nov) \\
\hline Normal & $41.3 \pm 4.8^{\mathrm{a}}$ & $39.4 \pm 2.6^{\mathrm{a}, \mathrm{b}}$ & $26.4 \pm 2.3^{c}$ & $32.9 \pm 2.4^{\mathrm{b}, \mathrm{c}}$ \\
\hline \multicolumn{5}{|l|}{ Abnormal: } \\
\hline Macrocephalic & $0.1 \pm 0.09^{\mathrm{a}}$ & $0.8 \pm 0.4^{a}$ & $0.3 \pm 0.2^{\mathrm{a}}$ & $0.0^{\mathrm{a}}$ \\
\hline Microcephalic & $0.8 \pm 0.4^{\mathrm{a}}$ & $0.7 \pm 0.2^{a}$ & $1.6 \pm 0.5^{\mathrm{a}}$ & $1.3 \pm 0.4^{\mathrm{a}}$ \\
\hline Bicephalic & $0.3 \pm 0.14^{\mathrm{a}}$ & $0.3 \pm 0.1^{\mathrm{a}}$ & $0.2 \pm 0.1^{\mathrm{a}}$ & $0.1 \pm 0.1^{\mathrm{a}}$ \\
\hline Malformed head shape & $6.3 \pm 2.9^{\mathrm{a}}$ & $3.8 \pm 1.4^{\mathrm{a}}$ & $8.2 \pm 3.2^{\mathrm{a}}$ & $7.5 \pm 2.9^{a}$ \\
\hline Malformed acrosome & $10.9 \pm 1.5^{\mathrm{a}}$ & $8.3 \pm 0.9^{\mathrm{a}}$ & $10.3 \pm 1.2^{\mathrm{a}}$ & $9.1 \pm 1.3^{\mathrm{a}}$ \\
\hline Abnormal mitochondrial sheath & $1.4 \pm 0.5^{\mathrm{a}}$ & $0.8 \pm 0.3^{\mathrm{a}}$ & $3.1 \pm 0.6^{\mathrm{b}}$ & $3.7 \pm 0.7^{b}$ \\
\hline Tightly coiled flagellum & $4.3 \pm 2.6^{\mathrm{a}}$ & $6.3 \pm 2.1^{\mathrm{a}}$ & $8.5 \pm 2.4^{\mathrm{a}}$ & $7.6 \pm 1.1^{\mathrm{a}}$ \\
\hline Bent midpiece with droplet & $11.2 \pm 5.0^{\mathrm{a}}$ & $15.5 \pm 1.7^{\mathrm{a}}$ & $14.0 \pm 2.4^{\mathrm{a}}$ & $13.6 \pm 2.7^{\mathrm{a}}$ \\
\hline Bent midpiece without droplet & $7.9 \pm 1.4^{\mathrm{a}}$ & $9.3 \pm 1.2^{\mathrm{a}}$ & $16.6 \pm 3.5^{\mathrm{a}}$ & $14.4 \pm 2.1^{\mathrm{a}}$ \\
\hline Proximal or distal droplet & $4.7 \pm 1.1^{\mathrm{a}}$ & $6.3 \pm 1.0^{\mathrm{a}}$ & $4.4 \pm 0.7^{\mathrm{a}}$ & $4.0 \pm 0.9^{\mathrm{a}}$ \\
\hline Bent flagellum & $1.8 \pm 0.9^{\mathrm{a}}$ & $1.2 \pm 0.3^{\mathrm{a}}$ & $1.6 \pm 0.5^{\mathrm{a}}$ & $1.5 \pm 0.6^{a}$ \\
\hline Biflagellate & $0.2 \pm 0.1^{a}$ & $0.2 \pm 0.7^{\mathrm{a}}$ & $0.0^{\mathrm{a}}$ & $0.8 \pm 0.7^{\mathrm{a}}$ \\
\hline Bent neck & $1.2 \pm 0.4^{\mathrm{a}}$ & $1.1 \pm 0.3^{\mathrm{a}}$ & $1.6 \pm 0.3^{\mathrm{a}}$ & $1.2 \pm 0.3^{\mathrm{a}}$ \\
\hline
\end{tabular}

$V$ alues are mean percentages \pm SFM.

Values within rows with different superscripts are significantly different $(P<0.05)$.

(Fig. 4a). Concentrations during the spring and autumn were similar $(P>0.05)$.

In contrast to $\mathrm{LH}$, mean FSH concentrations were high in both the autumn $\left(5.60 \pm 0.18 \mathrm{ng} \mathrm{ml} \mathrm{m}^{-1}\right)$ and winter $\left(5.48 \pm 0.26 \mathrm{ng} \mathrm{ml}^{-1}\right)$; no difference $(P>0.05)$ was observed between those two seasons. Mean FSH concentrations in the spring and summer were similar $\left(3.98 \pm 0.23 \mathrm{ng} \mathrm{ml}^{-1}\right.$ and $3.66 \pm 0.24 \mathrm{ng} \mathrm{ml}^{-1}$, respectively), and were lower $(P<0.05)$ than those measured during the winter and autumn (Fig. $4 \mathrm{~b}$ ).

The seasonal pattern of testosterone secretion was similar to that observed for LH. Overall, the mean testosterone concentrations were highest $(P<0.05)$ in the winter $\left(1.45 \pm 0.09 \mathrm{ng} \mathrm{ml}^{-1}\right)$ and lowest $(P<0.05)$ in the summer $\left(0.24 \pm 0.04 \mathrm{ng} \mathrm{ml}^{-1}\right)$ (Fig. 4c). Concentrations observed in the spring and autumn were intermediate and similar $(P>0.05$; $0.56 \pm 0.07 \mathrm{ng} \mathrm{ml}^{-1}$ and $0.45 \pm 0.12 \mathrm{ng} \mathrm{ml}^{-1}$, respectively).

There were significant $(P<0.05)$ correlations between $\mathrm{LH}$ and testosterone $(r=0.78), \mathrm{FSH}$ and testosterone $(r=0.38)$ and LH and FSH $(r=0.51)$ concentrations. Significant positive correlations $(P<0.05)$ were also found between testosterone and testicular volume $(r=0.41)$, testosterone and total sperm concentration $\mathrm{ml}^{-1}(r=0.35)$, testosterone and motile sperm concentration per ejaculate $(r=0.58)$, testosterone and ejaculate volume $(r=0.42), \mathrm{LH}$ and testicular volume $(r=0.52)$, and LH and motile sperm concentration per ejaculate $(r=0.37)$. Within seminal traits, there was a correlation between testicular volume and motile sperm concentration $(r=0.40)$.

\section{Discussion}

This is the first study to document a seasonal influence on both ejaculate and reproductive hormone traits in any felid species. The pattern of regression and recrudescence in testicular volume in the snow leopard has been shown to be associated with alterations in spermatogenic capacity, including overall ejaculate volume, sperm concentration and motility, and sperm morphology characteristics. Testicular volume in the snow leopard was greatest during the winter, coinciding with optimal ejaculate traits and high hormone concentrations.

Although spermic ejaculates were collected during all the seasons, they contained a relatively high proportion of malformed spermatozoa throughout the year. During the winter and spring, snow leopards produced an average of $60 \%$ abnormal sperm forms, which is comparable to the value reported by Howard $(1991 ; 58.7 \%)$. However, during the summer and autumn, the percentage of abnormal spermatozoa per ejaculate increased to about $70 \%$. Although the aetiology of sperm pleiomorphisms is unknown, increased structural abnormalities may result from disruptions during spermatogenesis (Lincoln, 1981). In this study, the seasonal decline in testosterone may have been related to the parallel rise in ejaculated sperm pleiomorphisms. The causal relationship between increased sperm abnormalities and reduced concentrations of androgens has been documented in both domestic and nondomestic felids. For example, cheetahs, pumas and teratospermic domestic cats secrete comparatively low concentrations of testosterone $\left(<0.5 \mathrm{ng} \mathrm{ml}^{-1}\right)$ and ejaculate a high frequency of pleiomorphic spermatozoa ( $>60 \%$ ).

Endocrine data in the snow leopard support the concept that seasonal regression and recrudescence of testicular function is due to changes in pituitary activity and specifically to alterations in LH and FSH secretion. The active phase of spermatogenesis during the winter months is characterized by high concentrations of LH, FSH and testosterone, and increased size of the testes and ejaculate quality. However, the seasonal peak in circulating FSH occurs during the autumn, which is in agreement with studies in other species in which the seasonal serum concentration of FSH increases before the onset of the breeding season and is associated with testicular recrudescence, rather than with maintaining spermatogenic activity (Lincoln, 1981; Soares and Hoffman, 1981; Sanford et al., 1984). This secretory pattern suggests that FSH is probably important in controlling the functional activity of Sertoli cells to regulate spermatogenesis. In addition, FSH may be partly responsible 

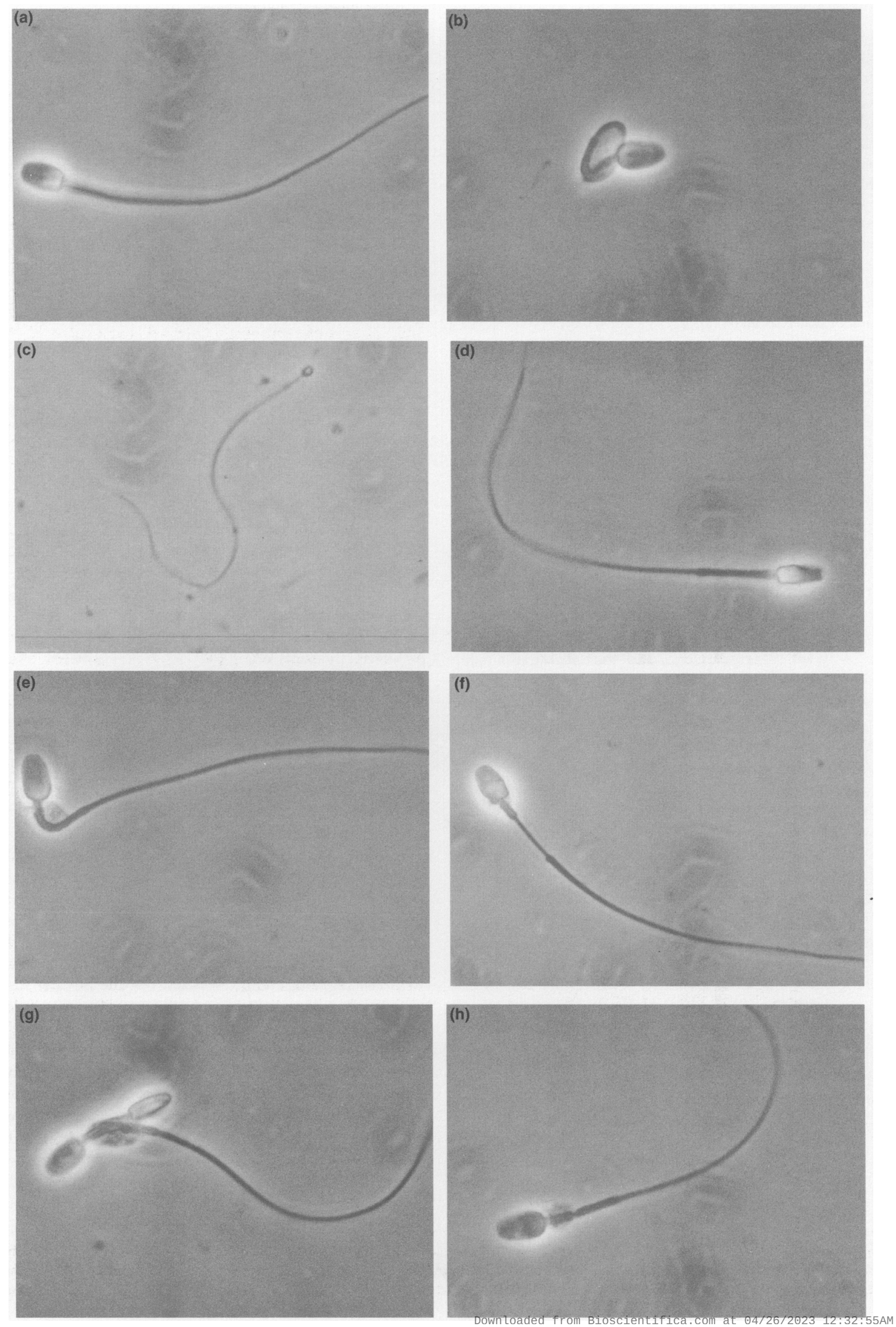

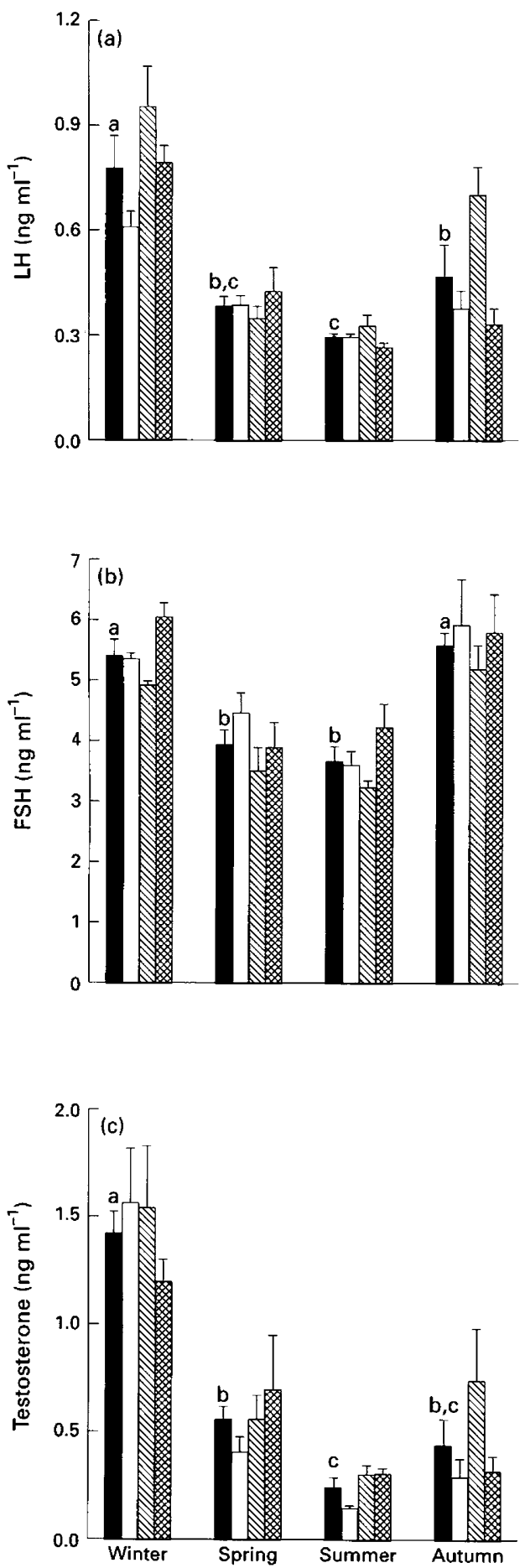

Fig. 4. Mean ( \pm SEM) (a) serum LH, (b) serum FSH and (c) serum testosterone concentrations in snow leopards on the basis of season. The columns represent values combined from all individuals $(\boldsymbol{\square})$, and

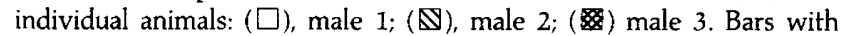
different superscripts are significantly different between seasons $(P<0.05)$ for enhancing LH-stimulated testosterone secretion by inducing an increase in the concentration of Leydig cell $\mathrm{LH}$ receptors (diZerega and Sherins, 1981).

Although $\mathrm{LH}$ concentrations began to increase in the autumn, peak values were not reached until the winter. $\mathrm{LH}$ modulates the secretory activity of the Leydig cells (diZerega and Sherins, 1981), and the positive correlation observed between LH and testosterone supports the concept that this functional relationship also exists in the snow leopard. Testosterone and FSH control spermatogenesis by acting directly on the seminiferous tubular epithelium (Courot and Ortavant, 1981); it would appear that this also applies to the snow leopard since testosterone secretion is greatest during the winter when reproductive performance is optimal.

On the basis of analysis of parturition records (this study) and patterns of reproductive steroids (Schmidt et al., 1993) in captive snow leopards, oestrous activity occurs between late December and early April. Field observations also concur that free-ranging females exhibit oestrus from January to March (Jackson, 1991). The potential of seasonal influences on oestrous and testicular cycles has also been documented in the clouded leopard (Wildt et al., 1986a, b; Yamada and Durrant, 1989) and Siberian tiger (Seal et al., 1985; Byers et al, 1990).

The clouded leopard is a tropical species found throughout Asia. Analysis of parturition records for captive females (latitude $36-55^{\circ} \mathrm{N}$ ) indicated that although young can be produced throughout the year, most females are in oestrus during autumn and winter; that is, they appear to respond to decreasing daylength (Yamada and Durrant, 1989). In another study, captive clouded leopard males (latitude $36-40^{\circ} \mathrm{N}$ ) exhibited a significant seasonal effect on testosterone secretion, and concentrations were highest in the winter; however, there was no effect of season on LH secretion or ejaculate traits (Wildt et al., 1986a, b).

The Siberian tiger is a temperate species inhabiting broadleaved coniferous forests in eastern Russia and northeastern China. Endocrine analysis of three females in captivity (latitude $45^{\circ} \mathrm{N}$ ) revealed that peak oestrous activity occurs from late January to early June (Seal et al., 1985). However, unlike the clouded leopard, the Siberian tiger exhibits an anoestrous period of up to 8 months. In a study of five male Siberian tigers, the highest testosterone concentrations were observed during the autumn and winter, but there was no effect of season on ejaculate quality (Byers et al., 1990). Thus, it would appear that seasonal effects on reproduction in the snow leopard are more conspicuous than in the Siberian tiger, and reproductive hormone concentrations positively correlate with changes in both size of the testes and quality of the ejaculate.

The study reported here demonstrates that optimal reproductive performance in the snow leopard is synchronized between the sexes and is seasonally mediated. There are a variety of environmental elements having the potential to affect seasonal reproduction including dietary (availability and source of food), physical (temperature or rainfall) and social factors. Studies on domestic cats showed that queens are

Fig. 3. Sperm forms detected in the snow leopard ejaculate: (a) normal; (b) coiled flagellum; (c) microcephalic defect and complete aplasia of mitochondrial sheath; (d) abnormal acrosome; (e) bent midpiece with cytoplasmic droplet; ( $f$ ) segmental aplasia of mitochondrial sheath; (g) bicephalic; and (h) proximal droplet with segmental aplasia of mitochondrial sheath. 
seasonally polyoestrus, with periods of anoestrus that are dependent on photoperiod and latitude (Scott and Lloyd-Jacob, 1959; Scott, 1970). Free-ranging queens in the northern hemisphere exhibit oestrus as early as January or February in response to increasing daylength (Herron, 1977; Stabenfeldt and Shille, 1977). However, when maintained under controlled conditions (a photoperiod of $12 \mathrm{~h}$ light: $12 \mathrm{~h}$ dark), queens can exhibit oestrous cyclicity throughout the year (Jemmett and Evans, 1977; Wildt et al., 1978). That photoperiod mediates seasonal reproduction in another felid, the tiger, is suggested by the observation that the duration of anoestrus was shortened in one female exposed to a longer period of daylight. The data reported here also suggest that photoperiod is a possible environmental mediator of both oestrous and testicular activity in the snow leopard.

The goal of any conservation-oriented captive propagation programme is to maintain genetic diversity in a stable population (Foose et al., 1986). Genome resource banks for gametes and embryos are potentially valuable tools in the management of captive species, since they can be used to help maintain the original genetic diversity of the population by extending the lifespan of individuals (Johnston and Lacy, 1991; Ballou, 1992; Wildt, 1992). The Species Survival Plan for the snow leopard, under the auspices of the American Zoo and Aquarium Association, has begun to establish a cryopreservation bank containing spermatozoa of genetically valuable, captive males that is destined for artificial insemination or in vitro fertilization. Data about ejaculates from this study will provide useful information for developing gamete collection strategies for the snow leopard.

The authors thank D. Morris, M. Junior, A. Holst and the keeper staff at the Henry Doorly Zoo for their cooperation and dedicated support.

\section{References}

Ballou JD (1992) Potential contribution of cryopreserved germ plasm to the preservation of genetic diversity and conservation of endangered species in captivity Cryobiology 29 19-25

Blomqvist L (1990) International Pedigree Book of Snow Leopards: Panthera uncia Vol. 6 pp 169-253 Ed. L. Blomqvist. Helsinki Zoo

Brown JL, Stuart LD and Chakraborty PK (1987) Endocrine profiles, testicular gonadotropin receptors and sperm production in hemi-castrated ram lambs Journal of Animal Science 65 1563-1570

Brown JL, Goodrowe KL, Simmons LG, Armstrong DL and Wildt DE (1988) Evaluation of the pituitary -gonadal response to $\mathrm{GnRH}$, and adrenal status, in the leopard (Panthera pardus) and tiger (Panthera tigris) Journal of Reproduction and Fertity 82 227-236

Brown JL, Citino SB, Bush M, Letunhardt J and Phillips LG (1991a) Cyclic patterns of luteinizing hormone, follicle-stimulating hormone, inhibin and progesterone secretion in the Asian elephant (Elephas maximus) Joumal of Zoo and Wildlife Medicine 22 49-57

Brown JL, Bush M, Packer C, Pusey AE, Monfort SL, O'Brien SJ, Janssen DL and Wildt DE (1991b) Developmental changes in pituitary-gonadal function in free-ranging lions (Panthera leo leo) of the Serengeti Plains and Ngorongoro Crater Journal of Reproduction and Fertility 91 29-40

Byers AP, Hunter AG, Seal US, Graham EF and Tilson RL (1990) Effect of season on seminal traits and serum hormone concentrations in captive male Siberian tigers (Panthera tigris) Journal of Reproduction and Fertility 90 119-125

Courot M and Ortavant R (1981) Endocrine control of spermatogenesis in the ram Journal of Reproduction and Fertility Supplement $3047-60$

diZerega GS and Sherins RJ (1981) Endocrine control of adult testicular function. The Testis pp 255-302 Eds H Burger and D de Kretser. Raven Press, New York
Foose TJ, Lande R, Flesness NR, Rabb G and Read B (1986) Propagation plans Zoo Biology 5 139-146

Gilpin ME and Soule ME (1986) Minimum viable populations: processes of species extinction. In Conservation Biology: The Science of Scarcity and Diversity pp 19-34 Ed. ME Soule. Sinauer Associates, Sunderland, MA

Herron MA (1977) Feline reproduction Veterinary Clinics of North America 7 715-722

Howard JG (1991) Assessment of semen quality and sperm function in non-domestic felids Proceedings of the Annual Meeting of the Society for Theriogenology pp 343-347

Howard JG, Bush M and Wildt DE (1986) Semen collection, analysis and cryopreservation in nondomestic mammals. In Current Therapy in Theriogenology pp 1047-1053 Ed. D. Morrow. W. B. Saunders, Philadelphia

Howard JG, Brown JL, Bush M and Wildt DE (1990) Teratospermic and normospermic domestic cats: ejaculate traits, pituitary-gonadal hormones and improvement of spermatozoal motility and morphology after swim-up processing Joumal of Andrology 11 204-215

Jackson R (1991) Snow leopards. In Great Cats: Majestic Creatures of the Wild pp 124-129 Eds J Seidensticker and S Lumpkin. Rodale Press, Emmaus

Jemmett JE and Evans JM (1977) A survey of sexual behavior and reproduction of female cats Journal of Small Animal Practice 18 31-37

Johnston LA and Lacy RC (1991) Utilization of sperm banks to maintain genetic diversity in captive populations of wild cattle. In Proceedings of the Wild Cattle Symposium pp 107-118 Eds DL Armstrong and T Gross. Henry Doorly Zoo, Omaha, NE

Lincoln GA (1981) Seasonal aspects of testicular function. In The Testis pp 255-302 Eds H Burger and D de Kretser. Raven Press, New York

Sanford LM, Howland BE and Palmer WM (1984) Seasonal changes in the endocrine responsiveness of the pituitary and testes of male sheep in relation to their patterns of gonadotropic hormone and testosterone secretion Canadian Journal of Physiology 62 827-833

Schmidt AM, Hess DL, Schmidt MJ and Lewis CR (1993) Serum concentrations of oestradiol and progesterone and frequency of sexual behaviour during the normal oestrous cycle in the snow leopard (Panthera uncia) Journal of Reproduction and Fertility $9891-95$

Scott PP (1970) Cats. Reproduction and Breeding Techniques for Laboratory Animals pp 192-208 Ed. ESE Hafez. Lea and Febiger, Philadelphia

Scott PP and Lloyd-Jacob MA (1959) Reduction in the anestrous period of laboratory cats by increased illumination Nature 1842022

Seal US, Plotka ED, Smith ID, Wright FH, ReindI NJ, Taylor RS and Seal MF (1985) Immunoreactive luteinizing hormone, estradiol, progesterone, testosterone and androstenedione levels during the breeding season and anestrus in Siberian tigers Biology of Reproduction 32 361-368

Smirnov MN, Sokolov AN and Zyryanov AN (1990) The snow leopard (Uncia uncia, Schreber 1776) in Siberia. In International Pedigree Book of Snow Leopards: Panthera uncia Vol. 6 pp 9-15 Ed. L. Blomqvist. Helsinki Zoo

Soares MJ and Hoffman JC (1981) Seasonal reproduction in the mongoose, Herpestes auropunctatus: 1. Androgen, luteinizing hormone, and folliclestimulating hormone in the male General and Comparative Endocrinology 44 350-358

Stabenfeldt GH and Shille VM (1977) Reproduction in the dog and cat. In Reproduction in Domestic Animals (3rd Edn) pp 499-527 Eds HH Cole and PT Cupps. Academic Press, New York

Wildt DE (1992) Genetic resource banks for conserving wildlife species: justification, examples and becoming organized on a global basis Animal Reproduction Science 28 247-257

Wildt DE, Guthrie SC and Seager SWJ (1978) Ovarian and behavioral cyclicity of the laboratory maintained cat Hormones and Behavior 10 251-257

Wildt DE, Bush M, Howard JG, O'Brien SJ, Meltzer D, von Dyk A, Ebedes $\mathrm{H}$ and Brand DJ (1983) Unique seminal quality in the South African cheetah and a comparative evaluation in the domestic cat Biology of Reproduction 29 1019-1025

Wildt DE, Howard JG, Hall LL and Bush M (1986a) Reproductive physiology of the clouded leopard: I. Electroejaculates contain high proportions of pleiomorphic spermatozoa throughout the year Biology of Reproduction 34 937-947

Wildt DE, Howard JG, Chakraborty PK and Bush M (1986b) Reproductive physiology of the clouded leopard: II. A circannual analysis of adrenalpituitary-testicular relationships during electroejaculation or after an adrenocorticotropin hormone challenge Biology of Reproduction 34 949-959

Yamada JK and Durrant BS (1989) Reproductive parameters of clouded leopards (Neofelis nebulosa) Zoo Biology 8 223-231 